\title{
EFFECTIVENESS OF DIFFERENT MECHANICAL BACTERIAL PLAQUE REMOVAL METHODS IN PATIENTS WITH FIXED ORTHODONTIC APPLIANCE: A SYSTEMATIC REVIEW AND META-ANALYSIS
}

\author{
EFICÁCIA DE DIFERENTES MÉTODOS DE REMOÇÃO MECÂNICA DE PLACA \\ BACTERIANA EM PACIENTES COM APARELHO ORTODONTICO FIXO: REVISÃO \\ SISTEMÁTICA E META-ANÁLISE
}

\author{
Matheus Melo PITHON ${ }^{1}$; Letícia Iandeyara Dantas Andrade SANT'ANNA ${ }^{2}$; \\ Felipe Carvalho Souza BAIÃ̃ ${ }^{2}$; Raildo da Silva COQUEIRO' ${ }^{1}$; Lucianne Cople MAIA ${ }^{3}$; \\ Luiz Renato PARANHOS \\ 1. Professor, Southwest Bahia State University UESB, Jequié, Bahia, Brazil. matheuspithon@ gmail.com; 2. Student of Dentistry \\ Southwest Bahia State University UESB, Jequié, Bahia, Brazil; 3. Professor of Department of Pediatric Dentistry and Orthodontics, \\ School of Dentistry, Federal University of Rio de Janeiro, Rio de Janeiro, Rio de Janeiro, Brazil; 4. Departament of Dentistry, \\ Universidade Federal de Sergipe, Lagarto, SE, Brazil.
}

\begin{abstract}
: the presence of fixed orthodontic appliances and its accessories tends to affect bacterial plaque removal, resulting in inadequate cleaning being performed by the patient. Thus, the aim of this systematic review and meta-analysis was to answer the following focal question: are the mechanical methods of oral cleaning effective for the reduction of bacterial dental plaque in patients with a fixed orthodontic appliance? A systematic search of the literature was conducted in the following databases: Scopus, PubMed, Cochrane, Web of Science, Embase, and Medline, in addition to Controlled Trials and Grey Literature, without limitations of language and year of publication. Furthermore, searches were also conducted in the reference lists of the articles selected. Included in the present review were clinical studies with patients undergoing therapy with fixed orthodontic appliances, which would, by means of comparison, evaluate the effectiveness of different mechanical bacterial plaque removal methods. The methodological quality of the articles included was evaluated in accordance with the methodological evaluation protocol, and was classified as high, moderate or low. In order to perform the meta-analysis, articles with high methodological quality were included. Analysis of subgroups was performed according to the type of intervention. The plaque index was defined as the continuous outcome variable, using the fixed effect when there was homogeneity among the articles, and the random effect in cases of heterogeneity. 1815 articles were found, of which only 23 fulfilled the eligibility criteria, with 17 being of high methodological quality and 6 of moderate quality. Of these, 18 included an analysis of the effectiveness of the conventional manual brush, 4 of the manual orthodontic brush, 15 of electric brushes, 3 of interdental brushes, 1 of dental floss and 4 or oral irrigation devices, and 1 of Siwak. In the qualitative evaluation of the studies, the use of these mechanical control methods was shown to be effective, with exception of the use of Siwak, which presented an increase in bacterial plaque. Moreover, the results of the meta-analysis indicated a significant reduction of -0.98 (IC $95 \%$ ) in the plaque index for the use of conventional manual brushes in the period of one month $(\mathrm{p}<0.001)$. There is a body of evidence that proves the effectiveness of mechanical bacterial plaque removal in patients using orthodontic appliances and accessories. The findings of the meta-analysis proved the effectiveness of the conventional manual brush. Further studies with better standardization of samples are required to strengthen the evidences.
\end{abstract}

KEYWORDS: Orthodontic appliance. Oral hygiene. Toothbrush.

\section{INTRODUCTION}

Dental bacterial plaque removal has been shown to be difficult in patients who use a fixed orthodontic appliance (LEUNG et al., 2006). The presence of orthodontic accessories enables the formation of bacterial niches that can only be removed by means of thoroughly performed chemical or mechanical cleaning methods (ATACK et al., 1996).

Among the mechanical methods commonly used, special mention is made of the use of toothbrushes, dental floss and more recently, dental irrigations. With regard to toothbrushes, these range from manual to electric types with the most varied designs, and may be of the conventional or orthodontic types (BOYD et al., 1989; RAFE et al., 2006). Electric or manual toothbrushes enable cleaning of the free surfaces of the teeth, however, they appear to be of little effectiveness for interproximal cleaning (ARICI et al., 2007).

When one thinks of the proximal surface of teeth, the available and most recommended methods are the use of dental floss and/or interdental brushes (HEINTZE et al., 1996). Devices such as oral irrigation may also facilitate the patient's cleaning of 
these surfaces, however, little information is found in the literature with respect to the efficiency of this method (HOOVER et al., 1968; LOBENE, 1969). Bearing in mind the diversity of methods existent, a question arises: which would be the most effective method for cleaning the teeth in a patient who uses a fixed orthodontic appliance? Therefore, in order to answer this question, the present systematic review / meta-analysis was conducted.

\section{MATERIALS AND METHODS}

The protocol of the present systematic review was registered in the PROSPERO database under the registration, and the authors followed the recommendations of the PRISMA statement for the report of this systematic review.

\section{Focused Question}

The aim of this systematic review was to answer the following guiding question: are the mechanical oral hygiene methods effective for the reduction of bacterial dental plaque in patients with a fixed orthodontic appliance?

\section{Search Strategy}

Based on the PRISMA guidelines (www.prisma-statement.org) for the production of this systematic review, systematic searches were conducted in the following databases: Scopus, PubMed, Web of Science, Medline, Embase, Cochrane and also in Controlled Trials and Grey Literature, with the purpose of identifying articles of a relevant nature, without limitation on year of publication or language. It is pointed out that search strategies were adequate in accordance with each database, using the following descriptors/ $\mathrm{MeSH}$ terms: orthodontics, orthodontic appliance, oral hygiene, toothbrush, toothpaste, dental floss, water, therapeutic irrigation, biofilm and dental plaque, and the following key words: waterjet, floss, oral hygiene, toothbrushes. The Search details are represented in Table 1.

Table 1. Database and method of search.

Database

(((orthodontic[All Fields] OR ("orthodontic appliances"[MeSH Terms] OR ("orthodontic"[All Fields] AND "appliances"[All Fields]) OR "orthodontic appliances"[All Fields] OR ("orthodontic"[All Fields] AND "appliance"[All Fields]) OR "orthodontic appliance"[All Fields])) AND (("oral hygiene"[MeSH Terms] OR ("oral"[All Fields] AND "hygiene"[All Fields]) OR "oral hygiene"[All Fields]) OR toothbrush[All Fields] OR ("toothpastes"[MeSH Terms] OR "toothpastes"[All Fields] OR "toothpaste"[All Fields]) OR ("dental devices, home care"[MeSH Terms] OR ("dental"[All Fields] AND "devices"[All Fields] AND "home"[All Fields] AND "care"[All Fields]) OR "home care dental devices"[All Fields] OR ("dental"[All Fields] AND "floss"[All Fields]) OR "dental floss"[All Fields]))) OR ((orthodontic[All Fields] OR ("orthodontic appliances"[MeSH Terms] OR ("orthodontic"[All Fields] AND "appliances"[All Fields]) OR "orthodontic appliances"[All Fields] OR ("orthodontic"[All Fields] AND "appliance"[All Fields]) OR "orthodontic appliance"[All Fields])) AND (("oral hygiene"[MeSH Terms] OR ("oral"[All Fields] AND "hygiene"[All Fields]) OR "oral hygiene"[All Fields]) OR ("water"[MeSH Terms] OR "water"[All Fields] OR "drinking water"[MeSH Terms] OR ("drinking"[All Fields] AND "water"[All Fields]) OR "drinking water"[All Fields]) OR ("therapeutic irrigation"[MeSH Terms] OR ("therapeutic"[All Fields] AND "irrigation"[All Fields]) OR "therapeutic irrigation"[All Fields])))) OR ((orthodontic[All Fields] OR ("orthodontic appliances"[MeSH Terms] OR ("orthodontic"[All Fields] AND "appliances"[All Fields]) OR "orthodontic appliances"[All Fields] OR ("orthodontic"[All Fields] AND "appliance"[All Fields]) OR "orthodontic appliance"[All Fields])) AND (""biofilms"[MeSH Terms] OR "biofilms"[All Fields] OR "biofilm"[All Fields]) OR ("dental plaque"[MeSH Terms] OR ("dental"[All Fields] AND "plaque"[All Fields]) OR "dental plaque"[All Fields])) AND ("oral hygiene"[MeSH Terms] OR ("oral"[All Fields] AND "hygiene"[All Fields]) OR "oral hygiene"[All Fields])) AND Clinical Trial[ptyp]

Results: 245 articles

(TITLE-ABS-KEY((orthodontic OR orthodonticappliance) AND (oralhygiene OR toothbrush OR toothpaste OR dentalfloss)) OR TITLE-ABS-KEY((orthodontic OR orthodonticappliance) AND (oralhygiene OR water OR therapeuticirrigation)) OR TITLE-ABS-KEY((orthodonticappliance OR orthodontic) AND (biofilm OR dentalplaque) AND oralhygiene))

Result: 269 articles

TS=((orthodontic appliance OR orthodontic) AND (oral hygiene OR toothbrush OR toothpaste OR dental floss)) OR TS=((orthodontic appliance OR orthodontic) AND (oral hygiene OR water OR therapeutic irrigation)) OR TS $=(($ orthodontic appliance OR orthodontic) AND (biofilm OR dental plaque) AND oral

Web of Science hygiene)

Result: 776 articles 


\begin{tabular}{|c|c|}
\hline & $\begin{array}{l}\text { ('oral hygiene'/exp OR 'oral hygiene' OR 'toothbrush'/exp OR 'toothbrush' OR 'toothpaste' OR 'dental } \\
\text { floss'/exp OR 'dental floss' OR 'water'/exp OR 'water' OR 'therapeutic irrigation'/exp OR 'therapeutic } \\
\text { irrigation' OR 'biofilm'/exp OR 'biofilm' OR 'dental plaque'/exp OR 'dental plaque') } \\
\text { Results: } 200 \text { articles }\end{array}$ \\
\hline $\begin{array}{l}\text { Medline Complete } \\
\text { (EBSCO) }\end{array}$ & $\begin{array}{l}\text { TX ( Orthodontic AND toothbrush AND dental floss AND therapeutic irrigation ) OR TX ( Orthodontic } \\
\text { AND toothbrush AND dental floss AND (dental plaque OR biofilm) ) OR TX ( Orthodontic appliance } \\
\text { AND toothbrush AND dental floss AND oral hygiene ) OR TX ( Orthodontic AND toothbrush AND } \\
\text { therapeutic irrigation AND water ) OR TX ( (orthodontic OR orthodontic appliance) AND (oral hygiene } \\
\text { OR toothbrush OR toothpaste OR dental floss)) } \\
\text { Results: } 84 \text { articles }\end{array}$ \\
\hline Cochrane & $\begin{array}{l}\text { (orthodontic OR orthodontic appliance) AND (oral hygiene OR toothbrush OR toothpaste OR dental floss) } \\
\text { in Title, Abstract, Keywords or (orthodontic OR orthodontic appliance) AND (oral hygiene OR water OR } \\
\text { therapeutic irrigation) in Title, Abstract, Keywords or (orthodontic OR orthodontic appliance) AND } \\
\text { (biofilm OR dental plaque) AND oral hygiene in Title, Abstract, Keywords in Cochrane Reviews } \\
\text { Results: } 241 \text { articles }\end{array}$ \\
\hline Controlled-Trials & $\begin{array}{l}\text { orthodontic AND therapeutic irrigation AND (oral hygiene OR toothbrush OR toothpaste OR dental floss) } \\
\text { Results: } 0\end{array}$ \\
\hline Open Grey & $\begin{array}{l}\text { orthodontic AND therapeutic irrigation AND (oral hygiene OR toothbrush OR toothpaste OR dental floss) } \\
\text { Results: } 0\end{array}$ \\
\hline
\end{tabular}

\section{Eligibility Criteria}

The following inclusion criteria had to be fulfilled in order for the articles found to be considered eligible for this systematic review: be a clinical study conducted with patients undergoing orthodontic treatment with a fixed appliance $(\mathrm{P})$ with mechanical oral hygiene (I), comparing among them the effects obtained by different mechanical methods (C) on the reduction of bacterial dental plaque $(\mathrm{O})$. Initial selection of the articles was made by reading the titles and abstracts of the articles found. The articles that presented no relationship with the topic, with patients without orthodontic appliance, which analyzed chemical control as the main focus, and with patients who had systemic diseases, or under the use of antibiotic therapy were excluded, as well as case reports, literature reviews and editorials.

Articles that did not present sufficient information in the title and abstract were read in full, enabling a decision to be made as regards its eligibility. The same applied to articles that presented a title within the topic, but the abstract was unavailable. The articles found in more than one database were counted only once. Selections were made independently by two researchers, and the results were compared to prevent possible discrepancies during data collection. In the event of disagreement between these two evaluators about the inclusion or exclusion of any article, a meeting with a third evaluator would occur, until a consensus among the three parties was reached.

A manual search in the list of references of the selected studies was also conducted with the goal of verifying possible studies that were not found in the database searches, so that they would be included in the review.

In cases in which there was need for additional data about any study, the authors of the study were contacted by e-mail in order to resolve the doubts related to eligibility of the article.

\section{Quality assessment and risk of bias}

For methodological evaluation of the studies included in this systematic review, a checklist was prepared, with fundamental criteria, which were elaborated based on the protocol of methodological evaluation used by (BARATIERI et al., 2011) in order to reduce the risk of biases.

\section{Data Extraction}

For extraction of the data from the articles included, they were read in full, and firstly, the data about the methodology of the study (sample, age and condition of participants and the intervention adopted and analyzed by the article) were collected.

After this, the methods of measurement adopted by the articles to obtain the results were collected, as well as a summary of the results and conclusions of the authors. 


\section{Statistical Procedure}

The primary outcome variable, plaque index was recorded as a continuous variable. Before proceeding with the meta-analysis, the studies were divided according to the type and time of the intervention, so that for comparative purposes, only meta-analysis of the studies with periods of intervention corresponding to one month (studies that related interventions of four weeks or 28 days were considered to be one month) were explored. The sub-groups formed were: intervention with manual toothbrush; with orthodontic toothbrush; with waterpik; and with electric toothbrush.

The effect size of each study was calculated as the standardized mean difference between the pre- and post-intervention measurements. For the meta-analysis, the Hedges g statistic was used as a formula for the standardized mean difference (SMD) under the fixed effects model. Next the heterogeneity statistic was incorporated to calculate the summary SMD under the random effects model (DERSIMONIAN and LAIRD, 1986). For analysis of the heterogeneity between the studies, the Cochran's $\mathrm{Q}$ and I-squared $\left(\mathrm{I}^{2}\right)$ tests were used. When homogeneity was detected, the fixed effect was considered for interpretation of the metaanalysis and when heterogeneity was detected, the random effect was considered (HIGGINS et al., 2003). The influence of a single study on the grouped effect was evaluated by means of analysis of the sensitivity in the four subgroups of different brushing interventions (FOLLMANN et al., 1992).

The level of significance adopted was $5 \%(\alpha$ $=0.05$ ). The data were tabulated and analyzed in the statistical software program MedCalc version 13.1.2.0 (MedCalc Software bvba, Ostend, Belgium).

\section{RESULTS}

\section{Search}

One thousand eight hundred and fifteen $(1,815)$ studies were found in the databases used. Of these, only 116 articles were considered potentially eligible. After this, all the non clinical studies, case reports, editorials, literature reviews and duplicates were removed. Thus 23 articles remained to be read in full and for evaluation of the methodological quality (Figure 1).
PHITON, M. M. et al.

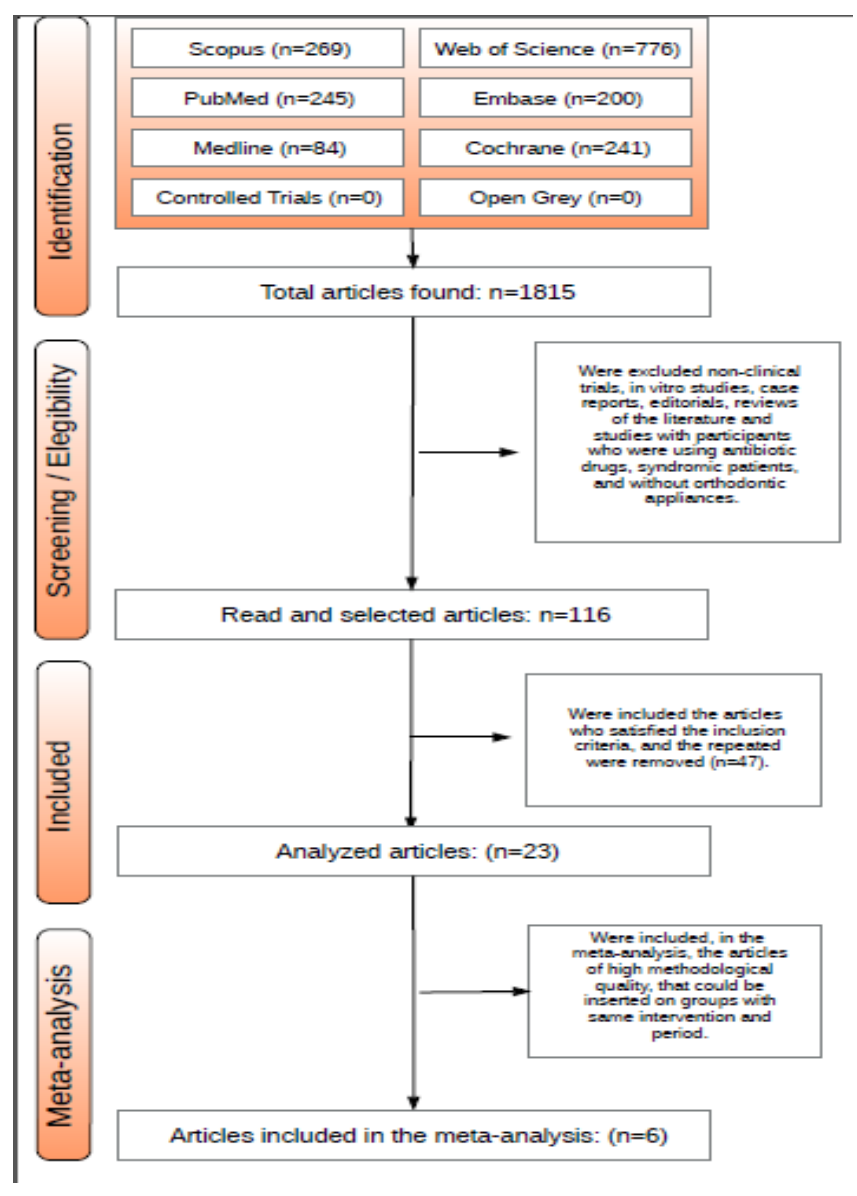

Figure 1. Flow Chart - Results of Searches.

\section{Quality Assessment}

For the final summary of the methodological quality of the articles, a graph was prepared in which each adequately fulfilled criterion was converted into a bar, thus the quantity of bars received by each article, represented its methodological quality. Those with 8 to 10 bars were considered high methodological quality, those with 5 to 7 bars, moderate methodological quality, and if articles with fewer than 5 bars were obtained, these would be considered of low methodological quality.

Of the articles included, 17 were evaluated as having high methodological quality (AL-TEEN et al., 2006; ARICI et al., 2007; BURCH et al., 1994; CLEREHUGH et al., 1998; COSTA et al., 2007; ERBE et al., 2013; GOMES et al., 2012; HICKMAN et al., 2002; HOHOFF et al., 2003; OUSEHAL et al., 2011; RAFE et al., 2006; SHARMA et al., 2008; THIENPONT et al., 2001; TRIMPENEERS et al., 1997; TROMBELI et al., 1995; WILCOXON et al., 1991), 6 as having moderate methodological quality (BOCK et al., 2010; HEASMAN et al., 1998; HEINTZE et al., 1996; JACKSON, 1991; KILICOGLU et al., 1997; 
KOSSACK and JOST-BRINKMANN, 2005; WOMACK and GUAY, 1968) and none with low methodological quality. Figure 2 illustrates the classification of articles according to the methodological evaluation criteria.

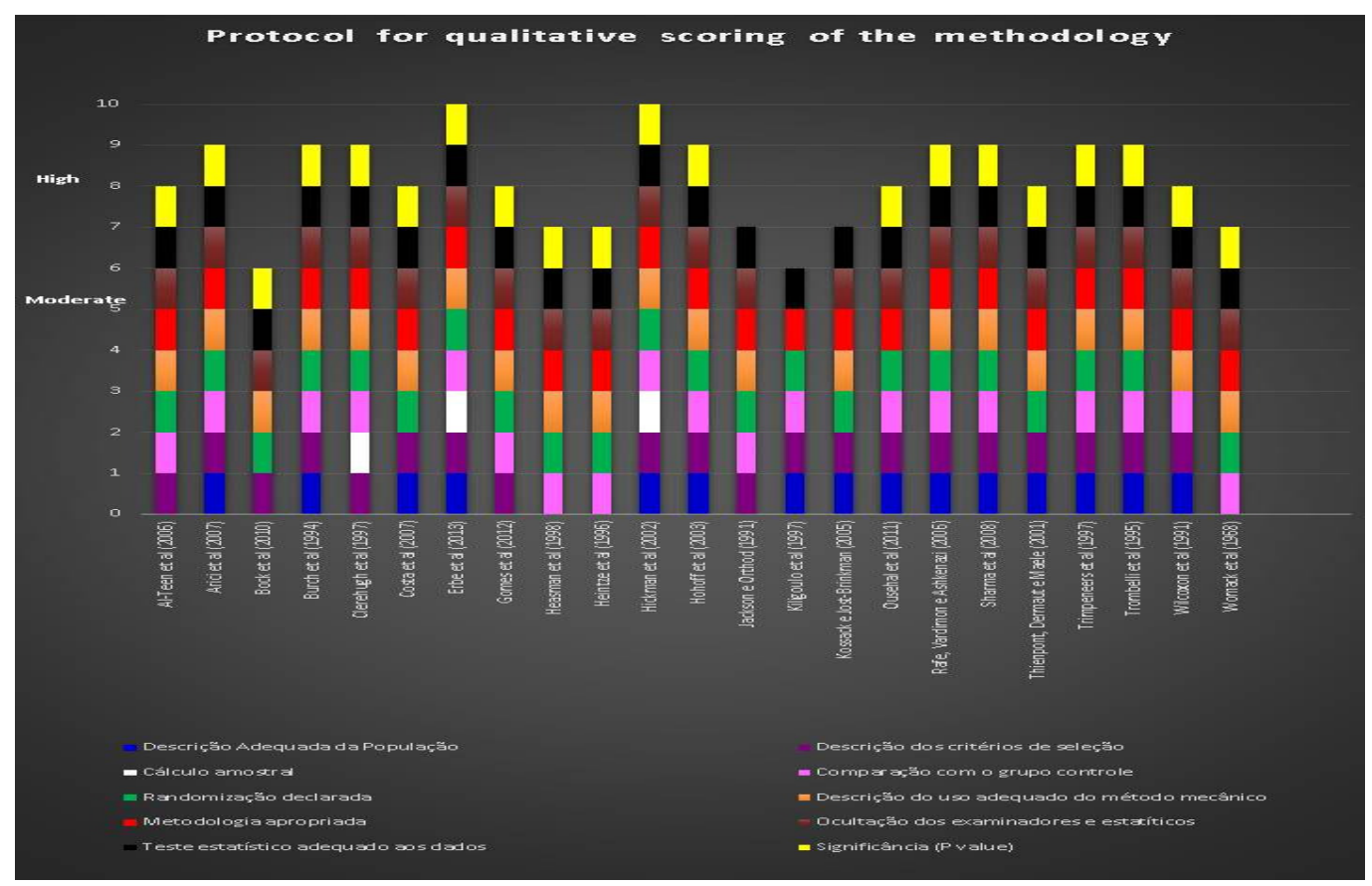

Figure 2. Protocol for qualitative scoring of the methodology.

As regards the description of the studies included and evaluated, Table 2 explains the characteristics of the participants - sample, age and condition - and the intervention of the treatment used - groups compared, prescription and total time of evaluation.

\section{Mechanical Methods Evaluated}

The mechanical methods used in the studies analyzed were conventional manual (AL-TEEN et al., 2006; BURCH et al., 1994; ERBE et al., 2013; GOMES et al., 2012; HEASMAN et al., 1998; HEINTZE et al., 1996; HICKMAN et al., 2002; HOHOFF et al., 2003; JACKSON, 1991; KILICOGLU et al., 1997; OUSEHAL et al., 2011; RAFE et al., 2006; SHARMA et al., 2008; THIENPONT et al., 2001; TRIMPENEERS et al., 1997; TROMBELI et al., 1995; WILCOXON et al., 1991; WOMACK and GUAY, 1968), orthodontic (AL-TEEN et al., 2006; ARICI et al., 2007; GOMES et al., 2012; RAFE et al., 2006), and electric brushes (BURCH et al., 1994; CLEREHUGH et al., 1998; COSTA et al., 2010; COSTA et al., 2007; ERBE et al., 2013; HEASMAN et al., 1998; HEINTZE et al., 1996; HICKMAN et al., 2002; JACKSON, 1991; OUSEHAL et al., 2011; THIENPONT et al., 2001; TRIMPENEERS et al., 1997; TROMBELI et al.,
1995; WILCOXON et al., 1991; WOMACK and GUAY, 1968), interdental brushes (ARICI et al., 2007; BOCK et al., 2010; HOHOFF et al., 2003), dental floss (SHARMA et al., 2008) and oral irrigation (BURCH et al., 1994; JACKSON, 1991; KOSSACK and JOST-BRINKMANN, 2005; SHARMA et al., 2008). Manual brushes with three heads and brushes with curved bristles were used in the studies of Rafe et al. (2006) and Arici et al. (2007), respectively, and siwak was studied by AlTeen et al. (2006).

As regards the prescription, in 12 studies mechanical cleaning twice a day predominated (CLEREHUGH et al., 1998; ERBE et al., 2013; GOMES et al., 2012; HEASMAN et al., 1998; HICKMAN et al., 2002; JACKSON, 1991; RAFE et al., 2006; SHARMA et al., 2008; THIENPONT et al., 2001; TRIMPENEERS et al., 1997; TROMBELI et al., 1995; WILCOXON et al., 1991). Whereas, duration of the process, when mentioned, ranged between 3 minutes (ARICI et al., 2007; HEASMAN et al., 1998; THIENPONT et al., 2001; TRIMPENEERS et al., 1997), 2 minutes (CLEREHUGH et al., 1998; COSTA et al., 2010; COSTA et al., 2007; ERBE et al., 2013; HEASMAN et al., 1998; HICKMAN et al., 2002; SHARMA et al., 2008; TROMBELI et al., 1995) and one minute (JACKSON, 1991). For oral 
irrigation, one study recommended performing it for one minute after brushing. Gomes et al. (2012) and Hohoff et al. (2003) recommended cleaning for 10 seconds per tooth.

With regard to cleaning the free tooth surfaces, 15 studies presented results with statistically significant difference in reduction of the plaque index when the conventional manual toothbrush was used (AL-TEEN et al., 2006; BURCH et al., 1994; CLEREHUGH et al., 1998; COSTA et al., 2007; ERBE et al., 2013; HICKMAN et al., 2002; HOHOFF et al., 2003; KILICOGLU et al., 1997; KOSSACK and JOST-BRINKMANN, 2005; RAFE et al., 2006; SHARMA et al., 2008; THIENPONT et al., 2001; TROMBELI et al., 1995; WILCOXON et al., 1991; WOMACK and GUAY, 1968). There were 6 studies for the manual orthodontic brushes (COSTA et al., 2007; GOMES et al., 2012; KILICOGLU et al., 1997; RAFE et al., 2006; WILCOXON et al., 1991). Where electric brushes were concerned, in the same way as for conventional brushes, 6 studies attained statistically significant difference (BURCH et al., 1994; COSTA et al., 2007; ERBE et al., 2013; TROMBELI et al., 1995; WILCOXON et al., 1991; WOMACK and GUAY, 1968), of which two found that the electric brush is as efficient as the manual type (BURCH et al., 1994; COSTA et al., 2007), whereas brushes with an orthodontic head, 2 articles found reduction in the plaque index with statistically significant results (CLEREHUGH et al., 1998; ERBE et al., 2013).The triple-headed brush also obtained a statistically significant reduction in the PI (RAFE et al., 2006), while the Siwak obtained an increase in plaque in the mandibular arch (AL-TEEN et al., 2006).

When cleaning of the interproximal regions was evaluated, the article of Bock et al. (2010) affirmed there was statistically significant reduction in the plaque index $(\mathrm{p}<0.001)$ with the interdental brush. The same occurred with studies that evaluated dental floss (HICKMAN et al., 2002) or waterpik (KILICOGLU et al., 1997). Table 2 presents the results and conclusions of the authors of the studies included.

Table 2. Description of Studies Included.

\begin{tabular}{|c|c|c|c|c|}
\hline \multicolumn{5}{|c|}{ Participants } \\
\hline Author & Total & Age (Mean) & Condition & Intervention \\
\hline \multirow[t]{2}{*}{$\begin{array}{l}\text { Al-Teen et al. } \\
(2006)\end{array}$} & 40 participants & $\begin{array}{l}17.20 \pm 4.01 \\
\text { years }\end{array}$ & $\begin{array}{l}\text { Use of fixed orthodontic } \\
\text { appliance for a minimum } \\
\text { of } 6 \text { months, with good } \\
\text { periodontal and medical } \\
\text { health. }\end{array}$ & $\begin{array}{l}\text { Groups: } \\
\text { - Manual Brush }(\mathrm{n}=10) \\
\text { - Orthodontic Brush }(\mathrm{n}=10) \\
\text { - Siwak Brush }(\mathrm{n}=10) \\
\text { - Siwak and Orthodontic Brush }(\mathrm{n}=10)\end{array}$ \\
\hline & & & & $\begin{array}{l}\text { Prescription: brushing } 3 \text { times a day in a period of } \\
21 \text { days. }\end{array}$ \\
\hline \multirow[t]{4}{*}{$\begin{array}{l}\text { Arici et al. } \\
(2007)\end{array}$} & $\begin{array}{l}30 \text { participants } \\
(12 \mathrm{M} \text { and } 18 \mathrm{~F})\end{array}$ & 13 to 16 years & $\begin{array}{l}\text { Second stage of treatment } \\
\text { with fixed Tip Edge } \\
\text { orthodontic appliance; }\end{array}$ & $\begin{array}{l}\text { Groups: } \\
\text { - Brush with curved bristles (CBT, Collis-Curve Inc.) } \\
(\mathrm{n}=30)\end{array}$ \\
\hline & & & $\begin{array}{l}\text { Dental plaque on } 10 \% \text { of } \\
\text { total tooth surface. }\end{array}$ & $\begin{array}{l}\text { - Orthodontic Brush and Interdental brush (Oral B) (n } \\
=30)\end{array}$ \\
\hline & & & & $\begin{array}{l}\text { All the participants went through the } 3 \text { brushing } \\
\text { protocols, interspersing groups of } 10 \text {, in random } \\
\text { sequence changed every } 4 \text { weeks. }\end{array}$ \\
\hline & & & & $\begin{array}{l}\text { Prescription: Brushing for } 3 \text { minutes following } \\
\text { orthodontist's instructions for each brush. }\end{array}$ \\
\hline \multirow[t]{2}{*}{$\begin{array}{l}\text { Bock et al. } \\
(2010)\end{array}$} & 110 participants & 11 to 17 years & $\begin{array}{l}\text { Use of fixed Tip-Edge } \\
\text { orthodontic appliance for } \\
6 \text { months. Without } \\
\text { relevant medical and oral } \\
\text { health (periodontal) } \\
\text { conditions. }\end{array}$ & $\begin{array}{l}\text { Groups: } \\
\text { - Interdental brush }\left(\mathrm{TePe}^{\circledR} \text { Compact Tuft with a long }\right. \\
\text { straight handle) }(\mathrm{n}=59) \\
\text { - Interdental brush }\left(\text { Elmex }{ }^{\circledR} \text { interdental brush No. } 6\right. \\
\text { with a short curved handle) }(\mathrm{n}=51)\end{array}$ \\
\hline & & & $\begin{array}{l}\text { Initial evaluation } \\
\text { performed by single } \\
\text { evaluator for }\end{array}$ & $\begin{array}{l}\text { Prescription: Use of interdental brush for } 12 \text { weeks } \\
\text { with left hand and } 12 \text { weeks with right hand. }\end{array}$ \\
\hline
\end{tabular}




\begin{tabular}{lll}
\hline & & $\begin{array}{l}\text { measurement of Plaque } \\
\text { Index (PI). }\end{array}$ \\
$\begin{array}{l}\text { Burch, Lanese } \\
\begin{array}{l}\text { and Ngan } \\
\text { (1994) }\end{array}\end{array}$ & $\begin{array}{l}21 \text { to } 48 \text { years } \\
\text { old }\end{array}$ & $\begin{array}{l}\text { Use of complete fixed } \\
\text { appliance for at least one } \\
\text { month and diagnosis of } \\
\text { generalized gingivitis. }\end{array}$
\end{tabular}

84 participants (37M and 47F)
10 to 20 years

15.2 years

\section{1 participants $(11 \mathrm{M} / 10 \mathrm{~F})$ \\ Costa et al. (2007)}

Erbe et al. (2013)
45 participants

14.6 years 14.6 years

Orthodontic appliance in both arches, minimum of 12 years of age and 8 natural front teeth.
Edgewise fixed orthodontic appliance, with history of brushing at least once a day.

Undergoing therapy with orthodontic appliance for at least one year, with a minimum of 20 teeth. Non smokers, without periodontal disease, and without use of medications in the 3 previous months, and without diseases that affect the periodontium.

\section{Groups:}

- Manual Brush ( $=15)$

- Oral irrigation appliance (WaterPik - output pressure of 55 to 65 psi using 400 to $500 \mathrm{ml}$ for each irrigation) and automatic brush (Plaque Control 2000) $(\mathrm{n}=16)$

- Oral irrigation appliance (WaterPik) and manual brush $(n=16)$

\section{Prescription:}

Manual brush was used in customary manner, and use of oral irrigator once a day.

\section{Groups:}

- Manual Brush ( $(n=43)$

- Electric brush with orthodontic head $(n=41)$

Prescription: Brush after breakfast and before sleeping, for 2 minutes, in a period of 8 weeks.

\section{Groups:}

- Manual Brush (Oral B Model 30) $(\mathrm{n}=21)$

- Electric Brush ((Braun Oral B 3D Plaque Remover) $(\mathrm{n}=21)$

- Ultrasonic Brush (Ultrasonex Ultima Toothbrush ${ }^{\circledR}$ $(1.6 \mathrm{MHz})(\mathrm{n}=21)$

All the participants passed through the 3 brushing protocols, for 30 days each, followed by an interval of 14 days, during which they were recommended to return to their regular oral hygiene procedures.

Prescription: Use of each brush 3 times a day for 2 minutes, for a period of 30 days in the sequence of each group, with an interval of 14 days, during which they returned to using the regular brushes and dental floss.

\section{Groups:}

- Manual Brush ( $\mathrm{n}=45)$

- Electric Brush (Oral-B Triumph with orthodontic brush head (OD17) $)(n=45)$ Electric Brush (Oral-B Triumph with Floss Action regular brush head $)(n=45)$

All the participants went through 3 brushing protocols.

Prescription: regular brushing for 2 minutes for 4 days and alternating the brush heads every time they brushed (morning and night).

Multibracket orthodontic appliance up to 2nd premolars or posterior molars. Maximum of 4 $\mathrm{mm}$ of anterior crowding, permanent dentition, maximum age of 35 years, without history of periodontal problems, and same types of mechanics

\section{Groups:}

- Conventional manual brush (Oral-B Sensitive) $(\mathrm{n}=32)$

- Manual orthodontic brush (Oral-B Orthodontic) $(\mathrm{n}=32)$

Prescription: Brush on waking and before going to sleep, 10 seconds per tooth. Two protocols were divided, Group 1: orthodontic brush on right side of the mouth and conventional brush on left side; and 


\begin{tabular}{|c|c|c|c|c|}
\hline & & & and orthodontic brackets. & $\begin{array}{l}\text { Group 2: Conventional brush on right side and } \\
\text { orthodontic brush on left side of mouth. For } 27.86 \\
\text { days, }\end{array}$ \\
\hline \multirow[t]{2}{*}{$\begin{array}{l}\text { Heasman et al. } \\
\text { (1998) }\end{array}$} & \multirow[t]{2}{*}{60 participants } & \multirow[t]{2}{*}{10 to 16 years } & \multirow[t]{2}{*}{$\begin{array}{l}\text { Orthodontic treatment for } \\
\text { at least } 12 \text { months, with } \\
\text { minimum of } 12 \text { brackets } \\
\text { or bands in each arch. }\end{array}$} & $\begin{array}{l}\text { Groups: } \\
\text { - Manual Brush (Oral B Manual Orthodontic brush) } \\
(\mathrm{n}=60) \\
\text { - Electric brush ( Braun electric toothbrush with } \\
\text { orthodontic head OD5-1) }(\mathrm{n}=60) \\
\text { - Electric brush with orthodontic head (HP550 } \\
\text { electric toothbrush with HP5924 head) }(n=60)\end{array}$ \\
\hline & & & & $\begin{array}{l}\text { All the participants went through all the protocols, for } \\
4 \text { weeks each. } \\
\text { Prescription: Brush for } 3 \text { minutes twice a day for the } \\
\text { electric brush and } 2 \text { minutes twice a day for the } \\
\text { manual brush. }\end{array}$ \\
\hline \multirow[t]{2}{*}{$\begin{array}{l}\text { Heintze et al. } \\
\text { (1996) }\end{array}$} & \multirow[t]{2}{*}{38 participants } & \multirow[t]{2}{*}{15.3 years } & \multirow[t]{2}{*}{$\begin{array}{l}\text { Use of fixed orthodontic } \\
\text { appliance on vestibular } \\
\text { surface in one of the } \\
\text { arches. }\end{array}$} & $\begin{array}{l}\text { Groups: } \\
\text { - Manual Brush (Elmex 29), interdental brush } \\
(\text { Elmex 1283) and dental floss (Oral-B) }(n=38) \\
\text { - Electric Brush (Interplak) }(n=38) \\
\text { - Electric Brush (Rota-dent) }(n=38) \\
\text { - Electric brush (Plaque remover EB5) }(n=38) \\
\text { - Electric brush (Plaque remover OD5) }(n=38) \\
\text {-EB5 } \\
\text { All the participants went through all the protocols, for } \\
4 \text { weeks each. After } 4 \text { weeks, making use of the } \\
\text { habitual oral hygiene practices, the patients received } \\
\text { a new brushing protocol. }\end{array}$ \\
\hline & & & & $\begin{array}{l}\text { Prescription: No specific recommendation was made } \\
\text { about how many minutes and how many times a day } \\
\text { to perform brushing. }\end{array}$ \\
\hline $\begin{array}{l}\text { Hickman et al. } \\
(2002)\end{array}$ & 60 participants & $\begin{array}{l}\text { I - Control } \\
\text { Group } 15.4 \pm \\
2.1 \text { years. } \\
\text { II - Test Group: } \\
14.9 \pm 1.4 \text { years. }\end{array}$ & $\begin{array}{l}\text { Use of fixed orthodontic } \\
\text { appliance in the two } \\
\text { dental arches. }\end{array}$ & $\begin{array}{l}\text { Groups: } \\
\text { - Manual Brush }(\mathrm{n}=29) \\
\text { - Electric Brush }((\text { Braun Oral B Plaque Remover D5 } \\
\text { with orthodontic head) }(\mathrm{n}=31) \\
\text { Prescription: } 15 \mathrm{~mL} \text { of mouthwash for } 30 \text { seconds, } \\
\text { twice a day. After breakfast and before going to } \\
\text { sleep. In a period of } 8 \text { weeks. }\end{array}$ \\
\hline \multirow[t]{2}{*}{$\begin{array}{l}\text { Hohoff et al. } \\
(2003)\end{array}$} & \multirow[t]{2}{*}{$\begin{array}{l}32 \text { participants } \\
\text { (Female) }\end{array}$} & \multirow[t]{2}{*}{25.9 years } & \multirow[t]{2}{*}{$\begin{array}{l}\text { Use of fixed lingual } \\
\text { appliance in maxillary or } \\
\text { mandibular arch. }\end{array}$} & $\begin{array}{l}\text { Groups: } \\
\text { - Manual brush (Elmex 29) (used in the first and third } \\
\text { quadrants) } \\
\text { - Interdental cleaning device (WaterPik Flosser (used } \\
\text { only in the second and fourth quadrant) }\end{array}$ \\
\hline & & & & $\begin{array}{l}\text { Prescription: Use the ICD device once per day for } \\
10 \text { seconds. }\end{array}$ \\
\hline Jackson (1991) & 20 participants & - & $\begin{array}{l}\text { All the patient's teeth } \\
\text { must have brackets } \\
\text { inserted in both arches. }\end{array}$ & $\begin{array}{l}\text { Groups: } \\
\text { - Manual Brush }(\mathrm{n}=5) \\
\text { - Electric Brush }(\mathrm{n}=5) \\
\text { - Manual Brush and irrigation }(\mathrm{n}=5) \\
\text { - Manual Brush and irrigation }(\mathrm{n}=5) \\
\text { Prescription: Twice a day, for } 1 \text { minute per } \\
\text { procedure. When there was irrigation, perform it for } \\
1 \text { minute after brushing. For a period of } 4 \text { weeks }\end{array}$ \\
\hline $\begin{array}{l}\text { Kliçoglu, } \\
\text { Yildirim and } \\
\text { Polater (1997) }\end{array}$ & 20 participants & $\begin{array}{l}\text { Between } 12 \text { and } \\
22 \text { years }\end{array}$ & $\begin{array}{l}\text { All the patient's teeth } \\
\text { must have brackets } \\
\text { inserted in both arches. }\end{array}$ & $\begin{array}{l}\text { Groups: } \\
\text { - Manual Brush (Oral B Model } 35 \text { toothbrush) }(\mathrm{n}= \\
\text { 10) }\end{array}$ \\
\hline
\end{tabular}




\section{Kossack and \\ Jost- \\ Brinkmann}

(2005)

\author{
40 participants \\ $(15 \mathrm{M} / 25 \mathrm{~F})$
}

\begin{abstract}
84 participants $(21 \mathrm{M} / 63 \mathrm{~F})$
\end{abstract}

13.9 years

19.41 years mandibular orthodontic appliance.
Use of fixed orthodontic appliance on mandibular and maxillary teeth, extending from at least teeth 16 to 26 , and 36 to 46 , and have used treatment for at least seven months.

\section{Rafe, \\ Vardimon and \\ Ashkenazi \\ (2006)}

\section{Sharma et al. (2008)}

Thienpont, Dermaut and Maele (2001)
94 participants (37M/57 F)

106 participants $(59 \mathrm{M} / 47 \mathrm{~F})$

33 participants $(15 \mathrm{M} / 18 \mathrm{~F})$
Between 11 and 17 years
$15.6 \pm 3.9$ years. appliance

Use fixed orthodontic appliance
Mean age 13 years and 6 months
Undergo orthodontic treatment in maxillary and mandibular arch

Prescription: No specific recommendation was made about how many minutes and how many times a day to perform brushing. For a period of 4 weeks

\section{Groups:}

- Manual Brush (Elmex ${ }^{\circledR}$ interX)

- Oral Irrigation (Water Pik ${ }^{\circledR}$ Sonic Speed sonic)

- Oral Irrigation (Water Pik ${ }^{\circledR}$ Sonic

Speed) and dental floss (Elmex ${ }^{\circledR}$ multi-floss Water Pik ${ }^{\circledR}$ Sonic Speed and Water Pik ${ }^{\circledR}$ Flosser)

All the participants passed through the 4 brushing protocols, for 4 weeks each, followed by an interval of 14 days, during which they were recommended to return to their regular oral hygiene procedures.

Prescription: The recommendation is in a site available to the author, which we were unable to access.

\section{Groups:}

- Manual Brush ( $\mathrm{n}=28)$ (Gum Super Tip)

- Electric brush $(\mathrm{n}=28)$ (Oral-B Cross Action)

Manual brush and mouth wash (Kin with $0.12 \%$ chlorhexidine and $0 \%$ alcohol $)(\mathrm{n}=28)$

Prescription: No specific recommendation was made as regards performing brushing and use of mouth wash. Each protocol was performed for a period of 4 weeks.

\section{Groups:}

- Manual Brush $(\mathrm{n}=31)$

- Orthodontic Brush $(\mathrm{n}=31)$

- Brush with three heads $(n=32)$

Prescription: Brush twice a day.

Groups:

- Manual Brush

- Dental waterjet and manual brush

- Manual Brush and waxed dental floss

Prescription: Use of manual brush for 2 minutes in the morning and at night, use DWJ and dental floss only once a day, at night. For a period of 4 weeks

\section{Groups:}

- Manual Brush (Oral B Advantage) $(\mathrm{n}=33)$

- Manual Orthodontic Brush (Lactona Orthodontic) $(\mathrm{n}=33)$

- Electric Brush ((Braun Oral B 3D) $(n=33)$

- Electric Brush (Philips-Jordan) $(\mathrm{n}=33)$

Prescription: Perform brushing twice a day, in the morning and at night, for 3 minutes. Each participant used each type of brush for the period of one month.

Mean age 12 years and 10 months
Undergo orthodontic treatment in maxillary and mandibular arch

\section{Groups:}

- Manual Brush $(\mathrm{n}=9)$

- Electric Brush (Interplak) $(\mathrm{n}=9)$

- Electric Brush (Philips) $(\mathrm{n}=9)$

- Electric Brush (Rotadent) $(\mathrm{n}=9)$ 
protocols, for 1 month each, followed by an interval of 1 month, during which they were recommended to return to their regular oral hygiene procedures.

Prescription: Perform brushing twice a day, in the morning and at night, for 3 minutes. Each participant used each type of brush for the period of one month. $\begin{array}{ll}\text { Trombelli et al. } & \begin{array}{l}20 \text { participants } \\ (10 \mathrm{M} / 9 \mathrm{~F})\end{array}\end{array}$

Wilcoxon et al. 20 participants (1991) $(12 \mathrm{M} / 8 \mathrm{~F})$
Between 12 and 53 years

\section{Between 11 and 26 years (mean of 15.5 years).}

\section{Undergo orthodontic treatment in at least one dental arch.}

Orthodontic treatment of all erupted teeth, except second and third molars.

\section{Groups: \\ - Manual Brush (Gum 311) $(\mathrm{n}=20)$ \\ - Electric Brush (Interplak) $(\mathrm{n}=20)$}

Prescription: Perform brushing for 2 minutes at least 2 times a day. Each participant used each type of brush in a period of 2 weeks.

\section{Groups:}

- Manual orthodontic brush (Oral-B 15) $(n=20)$

- Electric Brush (Interplak) $(\mathrm{n}=20)$

All the participants went through the 2 brushing protocols, for 1 month each.

Prescription: Perform brushing at least 2 times a day. Each participant used each type of brush for a period of 1 month.

\section{Groups:}

- Manual Brush $(\mathrm{n}=16)$

- Electric Brush $(\mathrm{n}=16)$

Prescription: Perform brushing at least after breakfast, after dinner and before going to sleep. Each participant used the two types of brushes for a period of 126 to 148 days.

Table 3. Methods of measurement, results and authors' conclusions.

\begin{tabular}{|c|c|c|c|}
\hline Author & $\begin{array}{l}\text { Method of } \\
\text { measurement }\end{array}$ & Result & Authors' Conclusions \\
\hline Al-Teen (2006) & $\begin{array}{l}\text { Quingly Hein } \\
\text { Index-Modified } \\
\text { byTuresky et al }\end{array}$ & $\begin{array}{l}\text { In the group with simple manual brushing the } \\
\text { plaque index increased in both the maxillary } \\
\text { and mandibular arch }(\mathrm{P}<0.001 \text { and } \mathrm{P}<0.01 \\
\text { respectively). As in the manual orthodontic } \\
\text { brush group }(\mathrm{p}<0.05) \text {. For the Siwak Group, } \\
\text { there was a statistically significant increase } \\
\text { only in the mandibular arch }(\mathrm{p}<0.001) \text {. In the } \\
\text { group composed of Siwak and manual } \\
\text { orthodontic brush, there was increase in plaque } \\
\text { only in the mandibular arch }(\mathrm{p}<0.05) \text {. }\end{array}$ & $\begin{array}{l}\text { The Siwak was shown to be efficient for } \\
\text { plaque control in patients with fixed } \\
\text { orthodontic appliances when compared } \\
\text { with the use of orthodontic brushes after } 21 \\
\text { days of use. The daily combined use of } \\
\text { Siwak and orthodontic brush provides a } \\
\text { superior performance to the use of only one } \\
\text { protocol. }\end{array}$ \\
\hline $\begin{array}{l}\text { Arici, Alkan and Arici } \\
\text { (2007) }\end{array}$ & $\begin{array}{l}\text { Percentage } \\
\text { Plaque Index } \\
\text { (PPI) and } \\
\text { Percentage of } \\
\text { plaque retained } \\
\text { in the } \\
\text { interproximal } \\
\text { regions (PIPI) }\end{array}$ & $\begin{array}{l}\text { For all the brushing protocols there was a } \\
\text { reduction in the PPI and PIPI values, compared } \\
\text { with baseline. However, there was no } \\
\text { significant reduction in the mean values of PPI } \\
\text { and PIPI for the curved-bristle toothbrush } \\
\text { (CBT) or orthodontic toothbrush (OT) } \\
\text { protocols }(\mathrm{P}>0,05) \text {. }\end{array}$ & $\begin{array}{l}\text { The CBT and OT protocols were not } \\
\text { capable of removing the plaque under } \\
\text { arches of the orthodontic appliances. } \\
\text { Therefore, the use of interdental brushes are } \\
\text { mandatory for removing bacterial plaque in } \\
\text { these patients. }\end{array}$ \\
\hline Bock et al. (2010) & $\begin{array}{l}\text { Attim's plaque } \\
\text { index }\end{array}$ & $\begin{array}{l}\text { The mean PI value was } 38 \% \text { at baseline }(\mathrm{T} 0) \text {. } \\
\text { During T0 - T1 there was a reduction of } 12 \% \text {. } \\
(\mathrm{p}<0.001) \text {. During the experimental period the } \\
\text { changes were not significant. There were no } \\
\text { statistically significant differences between the } \\
\text { two brushes in any period of time. }\end{array}$ & $\begin{array}{l}\text { The use of interdental brushes significantly } \\
\text { reduced the PI. Nevertheless, none of the } \\
\text { brushes were superior to any of the others. } \\
\text { However, the adolescent patients preferred } \\
\text { the use of the IDB in comparison with the } \\
\text { MTB, and thus, they would use them more } \\
\text { frequently, and they must be recommended } \\
\text { during orthodontic treatment. }\end{array}$ \\
\hline
\end{tabular}


Burch, Lanese and Ngan (1994) Silness and Loe plaque index

Clerehugh et al. (1998)

Costa et al. (2007)

Erbe et al. (2013)

Gomes et al. (2012)

Heasman et al. (1998)

Heintze, Jost-Brinkmann and Loundos (1996)

Hickman et al. (2002)

Hohoff et al. (2003)

Jackson (1991)

Kliçoglu, Yildirim and Polater (1997)
Visible Plaque Index

Approximal plaque index (API)

Silness and Loe plaque index

Orthodontic the Silness and Loe plaque index Digital plaque imaging analysis (DPIA)

Visible plaque index developed by Silness and Loe

O'Leary Plaque Index.

Silness and Loe plaque index

Patient hygiene performance

Bonded Bracket Index modification of (PHP) index
There were significant changes between the first and second month for the manual brush group with irrigation. The mean of the groups with oral irrigation suggested that both are equally successful in reducing plaque, and more successful than the manual brush group.

There was statistically significant reduction in the plaque index from 1.47 para 1.00 , between baseline and the eighth week for the electric brush group $(\mathrm{p}<0.001)$.

There was a significant difference for the group with ultrasonic brush, indicating that the ultasonic brush improves plaque reduction on oral surfaces $(\mathrm{P}=.007)$.

The DPIA scores for the three brushes presented no statistically significant difference in comparison with baseline values $(\mathrm{P}=0.856)$, with each group having a plaque level of $45 \%$ on an average. All three brushes presented statistically significant reduction in plaque after the beginning, ranging from $47 \%$ (manual) to $59.5 \%$ (electric brush with orthodontic head).

When comparing the two groups of brushes (conventional and orthodontic) no statistical difference was observed $(\mathrm{P} \leq 0.05)$ in the period of T0. However, there was significant improvement in the PIV with the use of the orthodontic brush in the period $\mathrm{T} 1(\mathrm{P}=0.002)$.

On the first visit, the plaque index in all the sites were significantly lower than the values at baseline $(P=0.05)$. There was no statistical difference between the brushes as regards the reduction of plaque.

As regards the plaque index, only the lingual surface presented statistically significant difference. Considering the plaque index of all the surfaces, the Rotadent (RD) brush showed the best results after 4 weeks compared with the other brushes, with $23 \%$ less plaque.

For the Electric Brush group, there was not statistical difference from baseline (visit 1) to visit 2 or 3 . ( $p=131$ and $p=145$ respectively). Whereas for the control group, there was a significant reduction in plaque fr om baseline to visit $2(\mathrm{p}<.001)$ and for visit $3 .(\mathrm{p}=.016)$.

At the end of the experiment, for both the maxillary and mandibular arches, the API of the Group ICD (Interdental cleaning device) was statistically significantly lower than the group without ICD.

There was no significant difference in the plaque index between the protocols.

A statistically significant reduction in plaque accumulation was presented on the vestibular and proximal surface of maxillary premolars and mandibular anterior teeth in the Ortho Group and on the vestibular surface of maxillary premolars for the Group Plus 35.
During the second month of the experiment, the oral irrigation device, in combination with manual or electric brushing, was of significant value in plaque reduction.

The use of the electric brush with orthodontic head could be beneficial in promoting gingival health in patients with fixed orthodontic appliances.

This study demonstrated that the plaque index was reduced on the vestibular surfaces of teeth with orthodontic brackets.

The study demonstrated that there was superiority of the rotary electric brush in comparison with the manual brush, and the brush with orthodontic head in comparison with the conventional head.

The present study did not provide evidence in favor of the use of manual orthodontic brushes by patients with fixed orthodontic appliances in permanent dentition. Therefore, it seems reasonable that the patient, together with his/her dentist selects a manual brush based on comfort and possibility of use, instead of allegations of greater efficiency.

The present study demonstrated that in four weeks, the electric brushes Philips HP550 and Braun D7 and the manual orthodontic brushes (Oral B) were equally efficient for the removal of plaque.

The RD brush may contribute to improvement in oral hygiene, in comparison with the manual technique (manual brush, interdental brush and dental floss). The same applies to the Plaque Remover brush, but only for patients with a low level of oral hygiene.

The electric brush with orthodontic head is as effective as the manual brush for cleaning around brackets.

The proximal plaque index was invariably or significantly lower in the group with ICDQ than in the group without ICDQ. However, the improvements in API were recorded in the clinical exam of all the quadrants.

There was no significant difference between the brushing protocols, however, the protocol in which the electric brush was used presented lower plaque indices.

The results showed that both brushes are equally effective in the preservation of oral hygiene. The presence of brackets and arch diminished the efficiency of brushing in the interproximal areas. This causes increase in the plaque index in this region. Interdental brushes or dental floss may help the patient. 


\section{Kossack and Jost- \\ Brinkmann (2005)}

Ousehal et al. (2011)

\section{Rafe, Vardimon and} Ashkenazi (2006)

Sharma et al. (2008)

Thienpont, Dermaut and Maele (2001)

Trimpeneers et al. (1997)

Trombelli et al. (1995)

Wilcoxon et al. (1991) Leary plaque índex.

Oral Debris Index (ODI)

Quigley and Hein plaque index

Silness and Löe Plaque Index.

Plaque indextooth (PIT), plaque indexbracket (PIB).

Turesky modification of the Quigley and Hein plaque index.

Plaque indextooth (PIT), plaque indexbracket (PIB). Quigley-Hein plaque index (PI).

O'Leary Plaque Index.

Womack (1968)
Afters 2 weeks with the use of the WaterPik Sonic Speed sonic toothbrush in conjunction with the WaterPik ${ }^{\circledR}$ Flosser, the scores improved significantly in comparison with baseline. This improvement was even more evident after four weeks. This combination was the only one to demonstrate significant improvements after four weeks using the manual brush Elmex ${ }^{\circledR}$ interX short brush-head.

For the group with the manual brush, the mean PI value was 1.12 before the study and 0.181 after the study $(p=0>0.05)$. For the electric brush group, the mean PI value before the study was 1.09 and went to 0.55 after the period of observation $(\mathrm{p}=0>0.05)$. For Group 3 (manual brush and mouth wash), the mean PI value before the study was 0.95 , and after conclusion of the study, it was $0.56(\mathrm{p}=0>$ $0.05)$.

After 4 weeks, the brush with three heads was significantly more efficient than the conventional manual brush and orthodontic plaque removal $(\mathrm{P}<0,001)$ and in removal of the plaque support $(\mathrm{P}<0.001)$.

The three treatment groups showed a statistically significant reduction in plaque from baseline to 2 and 4 weeks ( $<$ <.001). Comparing the group with Dental Water Jet and groups with dental floss and manual brush, the group DWJ was statistically significantly better than the other two groups $(\mathrm{p}<.001)$ in 2 and 3 weeks.

There was not statistical difference between the four types of brushes with regard to PIT and PIB.

Both manual brushing and the Philips electric brush had the same performance after one month of study. On conclusion of the study (two months) the manual brush presented higher values with regard to the plaque index. The Rotadent brush showed the lowest values during the entire study. There were no statistical differences between the groups.

The patients who used the counter rotational brush presented significantly lower indices $(\mathrm{P}=$ .008) than the patients who used the conventional brush. Nevertheless, the difference in plaque removal efficiency was statistically significant $(\mathrm{P}=.02)$ only when the counter rotational brush was used during the second week of evaluation.

The plaque indices were significantly lower ( $p$ $<0.01$ ) after brushing with the electric counter rotational brush for 2 months, than with the manual brush.

When comparing the two methods of brushing in the same arch and in the same period of time, in different individuals, a reduction in ODI was shown with the use of the electric brush $(0.0795$ $\pm 0.54)$
Brushing the teeth with a sonic brush is not sufficient, and must be complemented with an interdental device. Brushing with a sonic brush only, and also using the interdental device, the Water Pik Flosser, achieved better results than the use of only the manual brush Elmex ${ }^{\circledR}$ interX short brushhead.

Both the use of the electric brush and combination of the use of the manual brush with mouth wash were shown to be effective in the control of dental plaque.

We discovered that the brush with three heads was significantly more efficient in bacterial plaque removal and in the improvement of gingival health of patients with fixed orthodontic appliances.

This study showed that brushing and the use of dental flow or brushing and DWJ are efficient oral hygiene protocols. The DWJ was significantly better than the dental floss for the reduction of interproximal plaque in the entire mouth.

This study found no difference in efficacy between the two manual brushes and two electric brushes in children.

After the short term (1 month) and long term ( 2 months) evaluation, the results was that the manual brush was more efficient in the removal of supragingival plaque in adolescents with fixed orthodontic appliances. Of the three electric brushes tested, the Philips brush presented slightly better results than the Interplak brush, whereas the Rotadent brush very clearly showed inferior results to those of all the other brushes.

The results of this study indicated the superiority of the counter rotational brush over the manual brush in the removal of supragingival plaque in a period of 2 weeks.

The present study demonstrated the superiority of the electric counter rotational brush over the manual brush in dental plaque removal in patients with fixed orthodontic appliances.

The electric brush has a higher level of efficiency in comparison with the manual brush for cleaning the oral cavity in orthodontic patients. 


\section{Meta-analysis}

The studies that evaluated the water jet (BURCH et al., 1994; SHARMA et al., 2008), manual orthodontic brush (GOMES et al., 2012; RAFE et al., 2006), electric orthodontic brush (CLEREHUGH et al., 1998; HICKMAN et al., 2002) presented a high level of heterogeneity $\left(\mathrm{I}^{2}=\right.$ $96,16 \%, \mathrm{I}^{2}=94.53 \%$ and $\mathrm{I}^{2}=88.84 \%$, respectively), therefore, the meta-analysis was explored, but the results were not included. Seeing that the three subgroups were formed by only two studies, it was not possible to conduct the sensitivity analysis. Seven studies evaluated the effects of the method of brushing with a conventional manual brush
(BURCH et al., 1994; CLEREHUGH et al., 1998; GOMES et al., 2012; HICKMAN et al., 2002; OUSEHAL et al., 2011; RAFE et al., 2006; SHARMA et al., 2008) and after high heterogeneity $\left(\mathrm{I}^{2}=88.46 \%\right)$ being evaluated, we proceeded with the sensitivity analysis, with the study of Gomes et al. (2012) being identified as the one that had most impact on heterogeneity, and was excluded. Thus, the final analysis grouped six studies with 360 participants. The combined random effect of all the studies indicated that the brushing method with the manual brush promoted significant reduction in the plaque index (Figure 3).

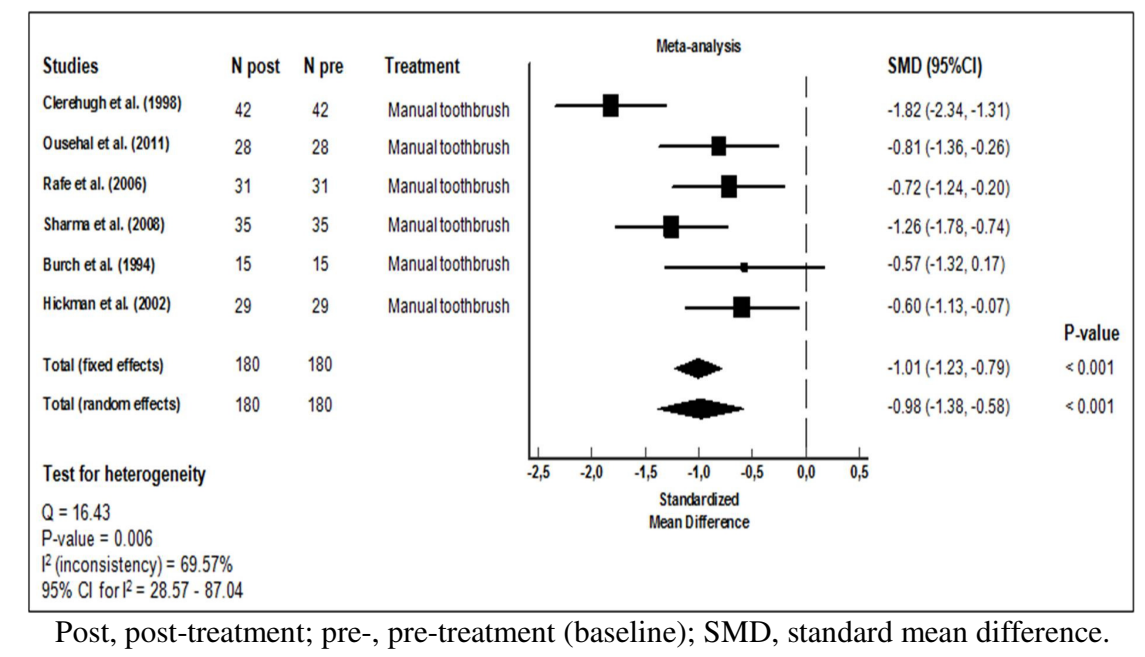

Figure 3. Meta-analysis of the effect of brushing with the manual brush, performed for 30 days, on reduction of the plaque index.

\section{DISCUSSION}

There is consensus about the difficulty in establishing adequate oral hygiene in patients undergoing use of a fixed orthodontic appliance. The presence of brackets, wires, elastics and rings favors bacterial accumulation that predisposes to the appearance of white spot lesions in enamel and marginal gingivitis (ATACK et al., 1996). Among the mechanical methods available for cleaning the oral cavity, there are toothbrushes with the widest variety of configurations, dental flosses and water jet appliances. However, a question arises: which would be the most effective method to prescribe specifically for this class of patients? Therefore, we proposed to conduct this study.

In order to minimize the bias of the studies, it is important to evaluate only the effect of the mechanical method, because the use of dentifrice could contribute to a more effective removal of bacterial plaque (DITTERICH RC, 2007). Of the studies selected, four did not specify whether or not dentifrice was used (KILICOGLU et al., 1997; OUSEHAL et al., 2011; TROMBELI et al., 1995; WOMACK and GUAY, 1968), fie mentioned the use of dentifrice irrespective of whether or not it contained fluoride (BURCH et al., 1994; GOMES et al., 2012; HOHOFF et al., 2003; JACKSON, 1991; WILCOXON et al., 1991), and fifteen affirmed the use of fluoridated dentifrice (AL-TEEN et al., 2006; ARICI et al., 2007; BOCK et al., 2010; CLEREHUGH et al., 1998; COSTA et al., 2010; COSTA et al., 2007; ERBE et al., 2013; HEASMAN et al., 1998; HEINTZE et al., 1996; HICKMAN et al., 2002; KOSSACK and JOSTBRINKMANN, 2005; RAFE et al., 2006; SHARMA et al., 2008; THIENPONT et al., 2001; TRIMPENEERS et al., 1997). In spite of this lack of standardization, it was found that in each study, particularly both the experimental and control groups used the same dentifrice, thereby avoiding biases in the results.

An effective oral hygiene technique is fundamental for bacterial plaque control. In view of 
this, the orthodontist must have knowledge of the existent techniques and know how to suit them to each patient, to obtain the best results (GUSMÃO et al., 2005). Of the studies analyzed, 7 made use of the Bass technique for the manual brushes (COSTA et al., 2007; HOHOFF et al., 2003; RAFE et al., 2006; THIENPONT et al., 2001; WILCOXON et al., 1991). For the electric brushes, the studies only related that they instructed the participants to use them in accordance with the manufacturers' recommendations (COSTA et al., 2007; GOMES et al., 2012; HEASMAN et al., 1998; JACKSON, 1991; TRIMPENEERS et al., 1997; TROMBELI et al., 1995; WILCOXON et al., 1991), except for the study of Burch et al. (1994) in which the type of movement performed by the brush (elliptical similar to the Bass sulcular technique) was informed. In addition, the modified BASS (RAFE et al., 2006), horizontal scrub technique (KILICOGLU et al., 1997; RAFE et al., 2006), and Bass combined with Charters techniques were used in the studies (HEASMAN et al., 1998). Other studies only informed that the participants received instructions (AL-TEEN et al., 2006; ARICI et al., 2007; BOCK et al., 2010; CLEREHUGH et al., 1998; HEINTZE et al., 1996; KOSSACK and JOST-BRINKMANN, 2005; OUSEHAL et al., 2011; SHARMA et al., 2008; TROMBELI et al., 1995), or gave a detailed description of the technique used (ERBE et al., 2013; GOMES et al., 2012; HEINTZE et al., 1996; WOMACK and GUAY, 1968).

As regards the performance of professional prophylaxis in the baseline period of the studies, AlTeen et al. (2006) and Rafe, Vardimon and Ashkenazi (2006) performed this for complete elimination of bacterial plaque. Arici et al. (2007) standardized participants to $10 \%$ of remaining plaque. Another four studies performed prophylaxis with scaling (JACKSON, 1991; TRIMPENEERS et al., 1997; TROMBELI et al., 1995; WILCOXON et al., 1991), one performed simple prophylaxis (BOCK et al., 2010), and 15 did not report having performed prophylaxis (BURCH et al., 1994; COSTA et al., 2007; ERBE et al., 2013; GOMES et al., 2012; HEASMAN et al., 1998; HEINTZE et al., 1996; HOHOFF et al., 2003; KILICOGLU et al., 1997; KOSSACK and JOST-BRINKMANN, 2005; OUSEHAL et al., 2011; SHARMA et al., 2008; THIENPONT et al., 2001; WILCOXON et al., 1991; WOMACK and GUAY, 1968). Prophylaxis performed before the beginning of the study was shown to be important, because it removed any debris that could facilitate the aggregation of bacterial dental plaque and consequently influence the results of the studies (AXELSSON, 1981).
From the results of the meta-analysis, in which the conventional manual brush attained a reduction of 1.01 in the plaque index in one month $(\mathrm{p}<0.001)$, one could affirm that this method is effective for mechanical control of bacterial plaque in orthodontic patients. This fact, corroborated by other studies included in this review and in the literature, affirmed that its effectiveness is similar to that of electric brushes (HEASMAN et al., 1998; OUSEHAL et al., 2011; THIENPONT et al., 2001), or even more efficient in the removal of supragingival plaque (TRIMPENEERS et al., 1997). Furthermore, Hickman et al. (2002) points out that when comparing manual and electric orthodontic brushes, only the manual type obtained a significant reduction in the plaque index $(\mathrm{p}<0.001)$. However, Rafe, Vardimon and Ashkenazi (2002), affirmed in their study that the triple-headed brush had been shown to be more effective than the conventional manual and orthodontic brushes. As it was not possible to conduct the meta-analysis with this method, there is no way of comparing the result of this method in the meta-analysis about conventional manual brushes.

With regard to interdental cleaning, Hickman et al. (2002) found a significant reduction in the PI with dental floss, nevertheless, a lower value than that obtained with the Waterpik $(\mathrm{p}<0.01)$, which also obtained a significant reduction $(p=0.026)$ in the study of Burch et al (1994). One could therefore affirm that mechanical bacterial plaque removal with the manual orthodontic brush is effective, and th at the use of dental floss and water jet are methods that complement this action with regard to interdental surfaces.

As regards the age-range of the participants in the studies those of an age ranging between 10 and 25 years predominated, with only 2 studies including older individuals: Wilcoxon et al. (1991) (12 to 53 years) and Burch et al. (1994) (21 to 48 years). One therefore perceives the need for studies with participants of advanced ages, as there are differences with regard to the ability to perform oral hygiene and nutritional diet, which may interfere in the results. For example, adolescents and children who present irregular eating habits (BAGGA, 2010), with a higher sugar intake in shorter time intervals (MAJEWSKI, 2001). Moreover, one observes that at present, orthodontic dental offices have received a growing number of adult patients (NATTRASS and SANDY, 1995).

The patient's cooperation with oral hygiene during orthodontic treatment is of great importance, and so is the guidance provided by the orthodontist with regard to the devices and comfortable cleaning 
techniques, suited to the routine of each patient, particularly in view of the appearance of diverse appliances on the market. One can therefore, infer that the clinical importance of this systematic review and meta-analysis lies in providing orthodontists with subsidies about the effectiveness of the main mechanical bacterial plaque removal methods, thereby allowing them to instruct their patients as regards the most adequate method for the maintenance of good oral health.

\section{CONCLUSION}

From this systematic review and metaanalysis, one may infer that:

- Brushing with a conventional manual brush is effective for reducing the plaque index, according to the results of the meta-analysis;

- The prescription most frequently indicated is mechanical cleaning of the teeth twice a day, with a time ranging from 1 to 3 minutes.

- The evidences found do not allow an evaluation by means of meta-analysis, of the effectiveness of the manual orthodontic brush, electric brushes, waterpik, and other methods, or to compare them with the conventional manual brush.

RESUMO: a presença de aparelhos ortodônticos fixos e seus acessórios tende a afetar a remoção da placa bacteriana, resultando em limpeza inadequada realizada pelo paciente. Assim, o objetivo desta revisão sistemática e metaanálise foi responder à seguinte questão norteadora: os métodos mecânicos de limpeza oral são eficazes para a redução da placa bacteriana dental em pacientes com aparelho ortodôntico fixo? Uma pesquisa sistemática da literatura foi realizada nas seguintes bases de dados: Scopus, PubMed, Cochrane, Web of Science, Embase e Medline, além de Ensaios Controlados e Literatura Cinzenta, sem limitações de idioma e ano de publicação. Além disso, as pesquisas também foram realizadas nas listas de referência dos artigos selecionados. Foram incluídos na presente revisão estudos clínicos realizados com pacientes submetidos à terapia com aparelhos ortodônticos fixos, os quais, por meio de comparação, avaliaram a eficácia de diferentes métodos mecânicos de remoção de placas bacterianas. A qualidade metodológica dos artigos incluídos foi avaliada de acordo com o protocolo de avaliação metodológica, e classificada como alta, moderada ou baixa. Para realização da metanálise, foram incluídos artigos de alta qualidade metodológica. A análise dos subgrupos foi realizada de acordo com o tipo de intervenção. O índice de placa foi definido como variável de desfecho contínuo, utilizando o efeito fixo quando houve homogeneidade entre os artigos e o efeito aleatório nos casos de heterogeneidade. 1815 artigos foram encontrados, dos quais apenas 23 preencheram os critérios de elegibilidade, sendo 17 de alta qualidade metodológica e 6 de qualidade moderada. Destes, 18 incluíram uma análise da eficácia da escova manual convencional, 4 da escova ortodôntica manual, 15 de escovas elétricas, 3 de escovas interdentais, 1 de fio dental e 4 de dispositivos de irrigação oral e 1 de Siwak. Na avaliação qualitativa dos estudos, a utilização destes métodos mecânicos de controle mostrou-se efetiva, com exceção do uso de Siwak, que apresentou aumento na placa bacteriana. Além disso, os resultados da meta-análise indicaram uma redução significativa de -0,98 (IC 95\%) no índice de placa para o uso de escovas manuais convencionais no período de um mês $(\mathrm{p}<0,001)$. Existe um conjunto de provas que comprovam a eficácia da remoção de placas bacterianas mecânicas em pacientes que utilizam aparelhos e acessórios ortodônticos. Os resultados da metanálise provaram a eficácia da escova manual convencional. Outros estudos com melhor padronização de amostras são necessários para fortalecer as evidências.

PALAVRAS-CHAVE: Aparelho ortodôntico. Higiene oral. Escova dental.

\section{REFERENCES}

AL-TEEN, R. M.; SAID, K. N.; ABU ALHAIJA, E. S. Siwak as a oral hygiene aid in patients with fixed orthodontic appliances. Int J Dent Hyg, Oxford, v. 4, n. 4, p. 189-97, Nov 2006.

ARICI, S.; ALKAN, A.; ARICI, N. Comparison of different toothbrushing protocols in poor-toothbrushing orthodontic patients. Eur J Orthod, Oxford, v. 29, n. 5, p. 488-92, Oct 2007.

ATACK, N. E.; SANDY, J. R.; ADDY, M. Periodontal and microbiological changes associated with the placement of orthodontic appliances. A review. J Periodontol, Indianapolis, v. 67, n. 2, p. 78-85, Feb 1996.

AXELSSON, P. Concept and practice of plaque-control. The American Academy of Pediatric Dentistry, Chicago, v. 3, n. Special, p. 101-13, 1981. 
BAGGA, D. K. Adult orthodontics versus adolescent orthodontics: an overview. Journal of Oral Health \& Community Dentistry, v. 4, n. 2, p. 42-47, 2010.

BARATIERI, C.; ALVES, M., JR.; DE SOUZA, M. M.; DE SOUZA ARAUJO, M. T.; MAIA, L. C. Does rapid maxillary expansion have long-term effects on airway dimensions and breathing? Am J Orthod Dentofacial Orthop, St. Louis, v. 140, n. 2, p. 146-56, Aug 2011.

BOCK, N. C.; VON BREMEN, J.; KRAFT, M.; RUF, S. Plaque control effectiveness and handling of interdental brushes during multibracket treatment--a randomized clinical trial. Eur J Orthod, Oxford, v. 32, n. 4, p. 408-13, Aug 2010.

BOYD, R. L.; MURRAY, P.; ROBERTSON, P. B. Effect of rotary electric toothbrush versus manual toothbrush on periodontal status during orthodontic treatment. Am J Orthod Dentofacial Orthop, St. Louis, v. 96, n. 4, p. 342-7, Oct 1989.

BURCH, J. G.; LANESE, R.; NGAN, P. A two-month study of the effects of oral irrigation and automatic toothbrush use in an adult orthodontic population with fixed appliances. Am J Orthod Dentofacial Orthop, St. Louis, v. 106, n. 2, p. 121-6, Aug 1994.

CLEREHUGH, V.; WILLIAMS, P.; SHAW, W. C.; WORTHINGTON, H. V.; WARREN, P. A practice-based randomised controlled trial of the efficacy of an electric and a manual toothbrush on gingival health in patients with fixed orthodontic appliances. J Dent, Guildford, v. 26, n. 8, p. 633-9, Nov 1998.

COSTA, M. R.; DA SILVA, V. C.; MIQUI, M. N.; COLOMBO, A. P.; CIRELLI, J. A. Effects of ultrasonic, electric, and manual toothbrushes on subgingival plaque composition in orthodontically banded molars. Am J Orthod Dentofacial Orthop, St. Louis, v. 137, n. 2, p. 229-35, Feb 2010.

COSTA, M. R.; SILVA, V. C.; MIQUI, M. N.; SAKIMA, T.; SPOLIDORIO, D. M.; CIRELLI, J. A. Efficacy of ultrasonic, electric and manual toothbrushes in patients with fixed orthodontic appliances. Angle Orthod, Appleton, v. 77, n. 2, p. 361-6, Mar 2007.

DERSIMONIAN, R.; LAIRD, N. Meta-analysis in clinical trials. Control Clin Trials, New York, v. 7, n. 3, p. 177-88, Sep 1986.

DITTERICH RC, R. M., VASCONCELOS, RASTELLI MC, PORTERO PP, SANTOS EB. "In vitro" antimicrobial activity of natural substances in toothpastes. Odontologia Clínico-Científica, Recife, v. 6, n. 5, p. 303-07, out/dez. 2007.

ERBE, C.; KLUKOWSKA, M.; TSAKNAKI, I.; TIMM, H.; GRENDER, J.; WEHRBEIN, H. Efficacy of 3 toothbrush treatments on plaque removal in orthodontic patients assessed with digital plaque imaging: a randomized controlled trial. Am J Orthod Dentofacial Orthop, St. Louis, v. 143, n. 6, p. 760-6, Jun 2013.

FOLLMANN, D.; ELLIOTT, P.; SUH, I.; CUTLER, J. Variance imputation for overviews of clinical trials with continuous response. J Clin Epidemiol, Oxford, v. 45, n. 7, p. 769-73, Jul 1992.

GOMES, L. K.; SARMENTO, C. F.; SEABRA, F. R.; SANTOS, P. B.; PINHEIRO, F. H. Randomized clinical controlled trial on the effectiveness of conventional and orthodontic manual toothbrushes. Braz Oral Res, São Paulo, v. 26, n. 4, p. 360-5, Jul-Aug 2012.

GUSMÃO, E. S.; JUVINO-SILVEIRA, R. C.; SANTOS, R. L. Inter-relação da Periodontia com a Ortodontia. In: (Ed.). In: Paiva, JS. Almeida, RS. Periodontia: a atuação clínica baseada em evidências científicas. São Paulo: Artes Médicas, 2005. p.423-25.

HEASMAN, P.; WILSON, Z.; MACGREGOR, I.; KELLY, P. Comparative study of electric and manual toothbrushes in patients with fixed orthodontic appliances. Am J Orthod Dentofacial Orthop, St. Louis, v. 114, n. 1, p. 45-9, Jul 1998. 
HEINTZE, S. D.; JOST-BRINKMANN, P. G.; LOUNDOS, J. Effectiveness of three different types of electric toothbrushes compared with a manual technique in orthodontic patients. Am J Orthod Dentofacial Orthop, St. Louis, v. 110, n. 6, p. 630-8, Dec 1996.

HICKMAN, J.; MILLETT, D. T.; SANDER, L.; BROWN, E.; LOVE, J. Powered vs manual tooth brushing in fixed appliance patients: a short term randomized clinical trial. Angle Orthod, Appleton, v. 72, n. 2, p. 135-40, Apr 2002.

HIGGINS, J. P.; THOMPSON, S. G.; DEEKS, J. J.; ALTMAN, D. G. Measuring inconsistency in metaanalyses. BMJ, London, v. 327, n. 7414, p. 557-60, Sep 62003.

HOHOFF, A.; STAMM, T.; KUHNE, N.; WIECHMANN, D.; HAUFE, S.; LIPPOLD, C.; EHMER, U. Effects of a mechanical interdental cleaning device on oral hygiene in patients with lingual brackets. Angle Orthod, Appleton, v. 73, n. 5, p. 579-87, Oct 2003.

HOOVER, D. R.; ROBINSON, H. B.; BILLINGSLEY, A. The comparative effectiveness of the Water-Pik in a noninstructed population. J Periodontol, Indianapolis, v. 39, n. 1, p. 43, Jan 1968.

JACKSON, C. L. Comparison between electric toothbrushing and manual toothbrushing, with and without oral irrigation, for oral hygiene of orthodontic patients. Am J Orthod Dentofacial Orthop, St. Louis, v. 99, n. 1, p. 15-20, Jan 1991.

KILICOGLU, H.; YILDIRIM, M.; POLATER, H. Comparison of the effectiveness of two types of toothbrushes on the oral hygiene of patients undergoing orthodontic treatment with fixed appliances. Am J Orthod Dentofacial Orthop, St. Louis, v. 111, n. 6, p. 591-4, Jun 1997.

KOSSACK, C.; JOST-BRINKMANN, P. G. Plaque and gingivitis reduction in patients undergoing orthodontic treatment with fixed appliances-comparison of toothbrushes and interdental cleaning aids. A 6-month clinical single-blind trial. J Orofac Orthop, Munich, v. 66, n. 1, p. 20-38, Jan 2005.

LEUNG, N. M.; CHEN, R.; RUDNEY, J. D. Oral bacteria in plaque and invading buccal cells of young orthodontic patients. Am J Orthod Dentofacial Orthop, St. Louis, v. 130, n. 6, p. 698 e11-8, Dec 2006.

LOBENE, R. R. The effect of a pulsed water pressure cleansing device on oral health. J Periodontol, Indianapolis, v. 40, n. 11, p. 667-70, Nov 1969.

MAJEWSKI, R. F. Dental caries in adolescents associated with caffeinated carbonated beverages. Pediatr Dent, Chicago, v. 23, n. 3, p. 198-203, May-Jun 2001.

NATTRASS, C.; SANDY, J. R. Adult orthodontics--a review. Br J Orthod, London, v. 22, n. 4, p. 331-7, Nov 1995.

OUSEHAL, L.; LAZRAK, L.; ES-SAID, R.; HAMDOUNE, H.; ELQUARS, F.; KHADIJA, A. Evaluation of dental plaque control in patients wearing fixed orthodontic appliances: a clinical study. Int Orthod, Paris, v. 9 , n. 1, p. 140-55, Mar 2011.

RAFE, Z.; VARDIMON, A.; ASHKENAZI, M. Comparative study of 3 types of toothbrushes in patients with fixed orthodontic appliances. Am J Orthod Dentofacial Orthop, St. Louis, v. 130, n. 1, p. 92-5, Jul 2006.

SHARMA, N. C.; LYLE, D. M.; QAQISH, J. G.; GALUSTIANS, J.; SCHULLER, R. Effect of a dental water jet with orthodontic tip on plaque and bleeding in adolescent patients with fixed orthodontic appliances. Am J Orthod Dentofacial Orthop, St. Louis, v. 133, n. 4, p. 565-71; quiz 628 e1-2, Apr 2008.

THIENPONT, V.; DERMAUT, L. R.; VAN MAELE, G. Comparative study of 2 electric and 2 manual toothbrushes in patients with fixed orthodontic appliances. Am J Orthod Dentofacial Orthop, St. Louis, v. 120 , n. 4, p. 353-60, Oct 2001. 
TRIMPENEERS, L. M.; WIJGAERTS, I. A.; GROGNARD, N. A.; DERMAUT, L. R.; ADRIAENS, P. A. Effect of electric toothbrushes versus manual toothbrushes on removal of plaque and periodontal status during orthodontic treatment. Am J Orthod Dentofacial Orthop, St. Louis, v. 111, n. 5, p. 492-7, May 1997.

TROMBELI, L.; SCABBIA, A.; GRISELLI, A.; ZANGARI, F.; CALURA, G. Clinical evaluation of plaque removal by counterrotational electric toothbrush in orthodontic patients. Quintessence Int, Berlin, v. 26, n. 3, p. 199-202, Mar 1995.

WILCOXON, D. B.; ACKERMAN, R. J., JR.; KILLOY, W. J.; LOVE, J. W.; SAKUMURA, J. S.; TIRA, D. E. The effectiveness of a counterrotational-action power toothbrush on plaque control in orthodontic patients. Am J Orthod Dentofacial Orthop, St. Louis, v. 99, n. 1, p. 7-14, Jan 1991.

WOMACK, W. R.; GUAY, A. H. Comparative cleansing efficiency of an electric and a manual toothbrush in orthodontic patients. Angle Orthod, Appleton, v. 38, n. 3, p. 256-67, Jul 1968. 